\title{
Analysis of the Perception of Belonging and the Commitment to the Generational Transition Empirical essay of a Mexican consortium of companies dedicated to foreign trade
}

\author{
${ }^{1}$ José G. Vargas-Hernández, M.B.A; Ph.D., ${ }^{2}$ Karla Yvohone Delon Bacre \\ ${ }^{I}$ Research professor. Department of Administration University Center for economic and Managerial Sciences, \\ University of Guadalajara, Periférico Norte 799 Edificio G-201-7, Núcleo Universitario Los Belenes \\ Zapopan, Jalisco C.P. 45100; México \\ ${ }^{2}$ Doctorado en Ciencias Administrativas Universidad Cristóbal Colón, Zapata 80, Col Flores Magón. \\ Veracruz, Ver. CP 91900,
}

\begin{abstract}
Generational succession is an issue that is of vital importance in family businesses, since the permanence of the company depends on the success of the process. All the steps to follow, as well as the literature on the subject, are studied in the case presented, which is limited to a Consortium of companies dedicated to foreign trade, whose corporate is located in the city of Veracruz, with 30 years in the market and that is in the process of transition from the Council Presidency of the father to his son. The analysis includes the existing generational differences in the way of thinking and therefore in the way of managing several companies on which more than 600 employees depend and seeks to identify if there are some variables that ensure the success of a generational succession process.
\end{abstract}

Keywords: Generational succession, Likert scale, millennial generation, baby boomer generation, generation X JEL: L22 and L25

\section{Resumen}

La sucesión generacional es un tema que cobra vital importancia en las empresas familiares, ya que del éxito del proceso depende la permanencia de la empresa. Todos los pasos a seguir, así como la literatura del tema, son estudiados en el caso presentado, mismo que se acota a un Consorcio de empresas dedicadas al comercio exterior, cuyo corporativo se encuentra en la ciudad de Veracruz, con 30 años en el mercado y que se encuentra en el proceso de transición de la Presidencia del Consejo del padre a su hijo. El análisis incluye las diferencias generacionales existentes en la forma de pensar y por ende en la forma de dirigir a varias empresas del cual dependen más de 600 empleados y busca identificar si existen algunas variables que aseguren el éxito de un proceso de sucesión generacional.

Palabras clave: Sucesión generacional, Escala de Likert, Generación "Y”, generación baby boomers, generación X.

\section{Introduction}

Family businesses are very important in the Mexican country because of the income they earn and the jobs they generate. Derived from the foregoing, it is fundamental to carry out the succession of the leader of said companies in a correct manner, since the continuity of the same depends on that. More importantly, when you are the leader of a group of companies.The process of succession in the leader of the companies must be studied and prepared several years in advance. The preparation includes since the successor has the knowledge and experience required, until the leader who is going to delegate their duties and position, is prepared to really leave in other hands what for many years came with good results. 
Another important part of the succession process that must be studied is the fusion of two generations, since, if not done correctly, it can generate important conflicts between the people involved. The ideal is to include as part of the processes, procedures, policies and values of the company the best, the experience of the first generation and innovation and new theories of the second.

This study focuses on a consortium of Mexican companies engaged in foreign trade with more than 30 years in the middle. The main objective is to describe the perception that shareholders, senior managers and employees in general have about their sense of belonging and commitment at a time of generational change in senior management in a Mexican Consortium of Companies Dedicated to Foreign Trade.

The specific objectives of this study are:

A. Identify the perception of the staff in relation to the managerial positions and the doubts that may be had when leaving the management of the Group in the hands of younger generations.

B. Describe the perception of executives and employees in middle management around an improvement in both the productivity of the company and the safety of processes at a time of generational change in senior management.

Based on the result of the objectives, it will be possible to identify if the succession process is successful or not, which will depend on the subsistence of the organization in the generational transfer.

\section{Background of the problem}

Family businesses are increasingly recognized for their importance both in the generation of wealth and in employment. It is expected that they will continue to play an important role in the economy of the countries thanks to their flexibility in the processes, agility in decision-making, personal treatment granted to clients and their constant review and improvement of their processes in order to compete with multinational companies, which, due to their size, lose that sensitivity and direct contact with clients (Friedman and Friedman, 1994).

It is not easy to find an exact definition of what a family business is. Longenecker, Moore and Petty (2001), conceptualize the family business as one characterized by ownership and some other participation of two or more members of the same family, in their life and operation. In the family business are considered particular elements in their way of deciding and achieving the proposed objectives, different to a non-family company, its administration seeks to family goals and the company go in the same direction; in a harmonic and integral way (Vallejo, 2007). Stempler (1998, cited in Cabrera, 1998), defines a successful succession as one in which all the parties involved in the succession process perceive the succession as favorable and there is a general satisfaction of each person who participated in the transition process.

In addition, there is no anger or hostility from one party to another. There is also a general perception of all the agents participating in the process that the family, the company and the non-family employees, the one who is going to be succeed and the successor were treated in the best possible way by the succession plan. For the family business, the process of succession is an issue that, due to its relevance, must be decided on the configuration of the new property, since whoever controls the property exercises the power, and, if it wishes, the direction of the company it can be delegated if it is decided to appoint a general director (Belausteguigoitia, 2010). Chrisman, Chua and Sharma (1998) cited by Quijano, Magaña and Pérez (2011), evaluated the following attributes in the possible successor:

1) The level of cooperation of the predecessor and the successor;

2) The age of the successor; and

3) The compatibility of goals between the successor and the founder of the company.

(C) 2019, IJSMS 
Regarding the level of relationships that the successor must have with other members of the family, they evaluate four aspects:

1) Respect for actively involved family members;

2) Respect for family members not involved;

3) Confidence of the family members; and

4) Ability to take with the members of the family.

These authors concluded that the most valued attributes in the successor are integrity, experience within the family business and commitment to the business. In contrast to other authors (Chittoor and Das, 2007, Chrisman et al., 1998, Haberman and Danes, 2007), the order of birth and gender were not classified as the most relevant.On the other hand, Sharma and Irving (2005) analyzed the commitment of the successor with the organization and developed an investigation where they establish four bases for such commitment, evaluating their antecedents and consequences, which depend on the unipersonal characteristics and experiences of the successors.

1) Affective commitment based on an emotional bond, characterized by mutual trust, shared values and the achievement of common goals;

2) Normative commitment based on a perception of the sense of obligation and of what should be,

3) A calculating commitment that considers the opportunity costs involved and the way to avoid or reduce them, and

4) Imperative commitment, which includes the perception of needs and the dependence on the organization as the only available resource of action for the successor.

Based on this research, they concluded that the successor in a family business, being a person very close to both the shareholders, and the person who is transferring power, has a very high commitment, to comply with the sufficient training that was required from the beginning to make the transition of power efficient and take advantage of all the experience that has been in the course of the life of the company. The same perception of commitment is observed in the person who leaves the leadership of the company. In both cases the commitment factor is very high as well as the involvement, both to preserve the company and what this means for the family name, as well as for the income that a large part of their family depends on.

\section{Delimitation of the problem}

Family shareholders feel theirs and therefore the responsibility to make it grow belongs to them. This feeling, in many cases, becomes a priority for managers, however, the level of involvement in the processes for it to grow is multifactorial. The professionalization of the shareholder is reported as a factor that influences the sense of belonging. It is identified that the shareholders with master's degree studies report a greater sense of belonging, than those who only have a high school or a bachelor's degree. In addition to the above, the perception of the family shareholders that belong to the Board of Directors, regarding the commitment to the organization and the sense of belonging as factors that influence the selection of the successor is high, since what they seek is the permanence of the family business and its growth (Quijano, Magaña and Pérez, 2011).

The present investigation is limited to the process of generational succession in the president of the Council through which a Consortium of companies engaged in Mexican foreign trade, family, with its corporate in the city of Veracruz, where the founder of which depend on more than 600 employees and their families. The founder was always clear that it was his son who was going to replace him and at the moment they are in that process, even if he does not think about getting away from the companies completely, he will remain only part of the council, but the presidency and therefore, the leadership, already his son will take over, who at the moment has 30 years.

In order to identify the problems that may prevent the generational succession change of this work from having the expected success, the Lewin model (1947) is used, which allows identifying the main elements for a programmed change. This model shows how the company is currently and the change it intends to make within the company, which consists of three stages. The defrost of the current state allows to analyze the restrictive and driving forces of

(C) 2019, IJSMS

Page 27 
the current situation that it is sought to modify in search of the desired situation. Modification or transition is the process of changing the situation in which the corresponding interventions are carried out transformations in the current processes to look for new behaviors at the individual and organizational level. The re-freeze or subsequent state is established when the desired change has been reached and the benefits of the change are achieved, which seeks the stability resulting from the modifications made. In figure 1 the model is exemplified.

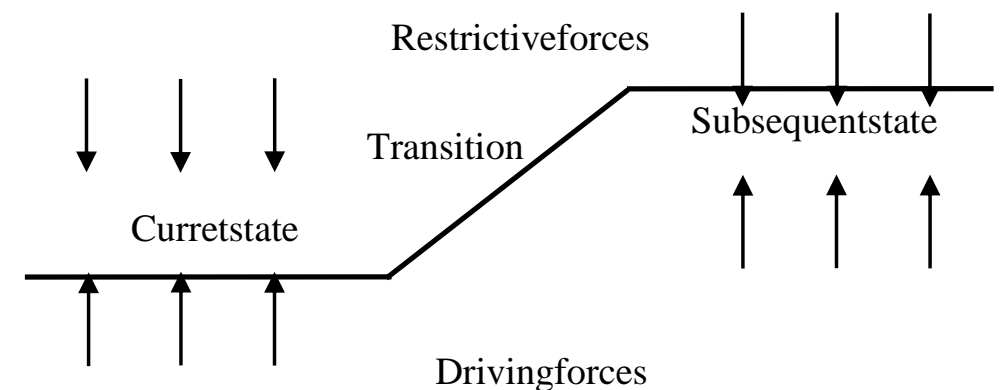

Figure 1. Kurt Lewin's change model Source: Own elaboration with information from Lewin (1947).

Considering this model, the driving and restrictive forces of the problem mentioned in Table 1 are identified:

Table 1. Driving forces and restrictive forces

Driving forces $\quad$ Restrictive forces 1. Opening to the change of the shareholders and 1 . Resistance to the change of the most senior staff
main managements 2. Generation change programming with enough 2 . Remove employees from their comfort zone
time.

3. Ability to adapt to the change of personnel in 3. Difference in the way of thinking of two very general different generations

Source: Own elaboration.

\section{Theoretical-conceptual and empirical review}

The good perception of the commitment and responsibility of the shareholders and of all those involved in the succession process is extremely important since that is the result of the success in the generational change of top management (Sharma and Irving, 2005). Oviedo (2004) considers perception as the fundamental process of mental activity, and assumes that other psychological activities such as learning, memory, thinking, among others, depend on the proper functioning of the perceptual organization process.

Regarding the involvement, belonging and commitment of the leaders when making a generational change in senior management in the family business, the Theory of the Agency (developed by Jensen and Meckling 1976, cited by Vilaseca, 2002) suggests that those with greater participation shareholders are more involved with the problems and their solution. Vilaseca (2002) examined the levels of identity, belonging and commitment as elements that influence the conflict of interests and objectives between shareholders who do not work in the family business and those who make up the senior management team of the same.

In this regard, the study reported that the degree of commitment to the company is negatively correlated with the number of family members in management positions and that, on the contrary, the commitment to raise the level of growth in non-managerial partners generates a positive attitude towards the company. Likewise, it states that the

(C) 2019, IJSMS

Page 28 
results of the mechanisms and processes implemented depend on the attention that the company places on the three subsystems of the organization: property, family and company.

For many family shareholders, the surname is a source of pride and its preservation becomes a motivator that generates not only a sense of belonging but a high level of commitment to the effort to preserve it. This feeling of pride and belonging can be the trigger for greater dedication and commitment in the company, which, in some cases, extends to other members of the family and those involved in the company who are not relatives, as long as there are not high levels of conflict (Vallejo, 2007).

This research is focused on analyzing the perception that the owners have in a moment of generational change in the top management of a Mexican consortium of companies dedicated to foreign trade, with offices and operations in the main customs and airports of the country, as well as other companies of the same branch, with corporate located in

Veracruz.

This group of companies has been 30 years in the market led by the majority shareholder during the same time. Preparing the relay process in the presidency, the CEO was replaced by a younger person, although with 15 years of experience in the company. The training process of the future president of the Consortium has included a degree in a prestigious university, work experience and various courses abroad, and will culminate with a postgraduate degree at an internationally renowned university.

The future leader and heir, started working in companies 3 years ago. Due to the size of the Group, family and nonfamily directors are involved within the structure, as well as key people who know, have several years in the company and great responsibility. The process of succession in a family business is extremely important, since that can depend on the results of the company until the possible disappearance of it if a plan with well-established commitments is not prepared in time. This succession plan must be decided on the configuration of a new property, since who controls the property exercises the power, and, if it wishes it, the direction of the company can be delegated if it is decided to name a general director (Belausteguigoitia, 2010).

The importance of family businesses in Mexico is not enough and the perception of these is of an undervaluation on the part of the sectors of this type of organizations. They are considered unprofessional as some tend to hire relatives only for the relationship but not for the quality of their work, which makes them inefficient. They do not usually enjoy a good reputation, because it is more common to hear stories of failure than of success (Nelton, 1993). The foregoing makes the study of the possible effects of a generational change in senior management even more important.

Due to the importance that family businesses have in different areas (economic, business, professional, political and university), their disappearance is a concern (Friedman and Friedman, 1994). It is estimated that only one out of every three family businesses succeeds to the next generation (Belausteguigoitia, 2004). Derived from the above, the process of succession takes great importance, since, if it is badly planned or not planned at all, the capacities that differentiate them from other types of organizations and that grant them an important competitive potential, may be threatened (Vancil, 1987, Handler, 1994).

The study of family businesses has been covered from the beginning with difficulties that do not finish solving. One of them refers to the point of departure of the discipline: its definition of the object of study.Aronoff and Ward (1995) point out that it is possible to consider whether this type of organization is merely a relic of the past destined to disappear or constitutes a business model to be imitated to adapt to the future economic environment.In this order of ideas, it can be taken into account that of every 100 family businesses only 34 manage to overcome the first generational change; Of those 34 , only $30 \%$ manage to reach the third generation.

However, $63 \%$ of family businesses want the continuity of their company, even though two thirds of family businesses do not feel prepared for the succession and half of their managers believe that they should never retire (PricewaterhouseCoopers and IEF, 2007), so it is important that the perception of the main executives and shareholders of the company on the generational change in senior management be positive.Some authors refer to the 
process of succession as a simple transfer of baton. Considering succession as a process seems to better define this fact, which characterizes family businesses anywhere in the world (Handler, 1989, Leach, 1993, Gallo, 1995, Ussman, 2004, Araya, 2011).

Succession is not a simple matter and, therefore, its planning is not either. The high mortality rates that characterize family businesses in the generational leaps are perhaps the best proof (Araya, 2011). Derived from the above, the generational succession in the top management must generate confidence in the managerial positions, since they are those that lead the operation of the company and achieve that the service provided is of quality to always have satisfied the clients.

In relation to the influence that relations, dynamics and family culture have on the succession process, it can be observed how in the most successful cases the succession process in the company has been accompanied by a cultural revolution in the family so that, as the successors mature / children, the predecessor / patriarch is giving way in his position and gives way to more collaborative and participatory patterns. In the less successful cases, there seems to be a coincidence that the predecessor finds it difficult to recognize the maturation process of his children and to abandon the patriarchal character, both in the company and in the family, generating feelings of discouragement, frustration and even tensions and distrust between family members.

As a result of the foregoing, the succession plan must be so well founded and planned that it achieves that the company, but especially the management positions, perceive an improvement by merging experience with updating, through a proper training of the successors.

The challenge for the succession of the highest positions in family businesses is in the management of specific or critical knowledge (Cabrera Suárez et al., 2001), transmitting the accumulated experience, but preserving family values and traditions for the next generation. To do this, it needs to prepare a body of trusted executives who meet the demands of changing leadership and provide opportunities for non-family professionals. Likewise, meet the requirements and needs of family members in individual terms, while the development and needs of non-family members will be strictly assumed according to the company's requirements. It is the best way to make this process work (García-Tenorio and Pérez, 2009).

\section{Hypothesis}

The objective of the present investigation is to determine the perception of the sense of belonging and commitment of the employees of the Consortium part of the study, in a process of generational succession in the leader of the same. This leads us to the following hypotheses:

Ho: There is no change in the perception of commitment and sense of belonging of employees during a process of generational change in the leader of the Consortium.

Ha: There is a change in the perception of the commitment and sense of belonging of the employees during a process of generational change in the leader of the Consortium.

And specifically:

Hi: Is the success of a process of generational succession in the leader of a group of family businesses dependent on the commitment and sense of belonging of the employees of the same?

\section{Method of Organizational Development}

The design of this research seeks to describe the perception of the shareholders, the main executives and general staff of the middle managers of a family Consortium of companies engaged in foreign trade, during a generational change regarding the commitment to the organization and sense of belonging. Since it focuses on perception (the way subjects perceive a situation), it is a qualitative research. The quantitative method is used for the statistical

(C) 2019, IJSMS

Page 30 
analysis of the responses of the applied surveys, to identify if there is any change in the perception of the sense of belonging and level of commitment in shareholders, senior executives and middle management staff to have a generational change in the top management. The information obtained serves to generate enough information to be able to conclude if the perception changes positively or negatively in said members. The method that will be used for the collection of information will be descriptive through surveys, as well as observation during the transition period.

Because of its source, it is mixed, since, in order to study the impact of generational change on senior management, documentary and field research is required, based on documents such as the consultation of books, articles or essays in magazines, newspapers and any document with academic validity, which will be complemented with field research to be carried out based on surveys and observations. For its usefulness, it is applied since it seeks the use of the knowledge that is acquired with the purpose that the result of the investigation can serve to improve the process of generational change or in its case, demonstrate that the process that has been applied It is effective.

For its objective it is descriptive because it is a definition of the current situation of the consortium under study and the moment that is currently happening during the generational change; deepening the reaction of shareholders and senior managers during this change (both in sense of belonging and commitment level).For the management of information is an analytical research, since it seeks to analyze what is happening at a particular time during a situation of generational change and changes that may affect the company.

\section{A. Diagnostic instrument}

The questionnaire used (developed by Herrera (2012) and adapted by Jurado 2014, consists of three parts: the first measures the commitment that the respondents have with the company, the second measures to what degree they identify with the company and the third part the motivation that they receive in their daily activities. The instrument was an own elaboration using the modality of Likert scale also known as summative evaluation, where some help items were taken. In this type of scale, the level of agreement or disagreement is specified with a statement totaling the scores to analyze the results based on an established range. The questions used in the interviews of the current president and the successor, were of own evaluation, designed exclusively for the purposes of this work.

\section{B. Alternative solution}

If, as a result of the investigation, it is concluded that there is a change in the perception of employees at all levels in a high percentage during the process of succession, they would have to take different actions from the current ones, such as:

1) Activities to motivate staff explaining the benefits of the succession process

2) Integration to the succession process of all personnel

3) Work meetings

\section{Development of the theme}

The research technique used is field research, developed with the implementation of collection techniques and analysis of results based on surveys applied to the main managers in charge of the main areas of the company and employees of the middle managers, through different interviews, the president and the successor and with the observation that were made at different times in the company. The above with the aim of describing the perception of the main stakeholders and leaders of the Consortium of research base companies, regarding the commitment to the organization and sense of belonging as factors that influence the success of a period of succession in the Presidency. of the group.

In a first stage, semi-structured surveys were conducted with the majority shareholders who are the president and his successor, with the purpose of presenting the objectives of the investigation, and obtaining their authorization to continue with the investigation.

(C) 2019, IJSMS

Page 31 
In the second stage, the surveys were applied to minority shareholders and management positions, to personnel in management positions already employed in middle positions in the Consortium that is part of this study. Based on the answers provided it was able to describe if a generational change in senior management, changes on the perception of senior executives and other shareholders and if a lack of confidence or improvement in the processes with this generational change in the group's leaders is perceived in the management positions.

In the third stage, the behavior of those involved in the study during different times and circumstances were analyzed, which helps to describe the impact of the aforementioned generational change.

This research is based on the methodology in the study of Vilaseca (2002), who demonstrates, from a positivist perspective, the relationship between shareholding, the degree of commitment, identity and the sense of belonging perceived by the scorecards in family businesses, adapting it to include senior managers who are not members of the Group, but who have been in charge of the area for more than 10 years. All of the above, during a period of succession of the Group president, which is the highest position, occupied by the majority shareholder.

This study is of a descriptive type, which is elaborated based on the information that is collected from the surveys. The design is not cross-sectional since data is collected at a single moment in its natural context, through surveys applied to the shareholders and the rest of the executive body. With the purpose of describing the perception at the present time of the main Directors (including the president and his substitute) during the generational change in senior management.

The questionnaires were administered directly to each of the Group's main executives, as well as to the middle management staff, to the successor as head of the Innovation Department, and to the president, a personal interview was applied. Each individual received an email with the questionnaire. Separately, the behavior of each one of those involved was observed at different times during the development of the investigation. A simple statistical analysis was used to process the information. Initially, it allowed a descriptive and frequency analysis of the main variables. Later, an analysis of variance was carried out, where the statistically significant differences present in each of the variables were determined.

In order to carry out the study, it is necessary to follow a series of steps, which are presented below:

1) The contact with the subjects was made electronically to apply the instrument individually.

2) After the above, we proceeded to tabulate the data to generate the presentation of results.

3) According to the data obtained in the tabulation, results were obtained according to what is presented in the graphs through the basic statistical analysis.

4) Based on what was analyzed in the interpretation of results, a discussion was reached, comparing with what was gathered in the theoretical framework.

5) Through the discussed and analyzed conclusions of the investigation were made, and at the same time recommendations were generated as an alternative to solve the findings.

6) Finally, an improvement proposal was generated for the employers as an alternative for the solution.

The statistical methodology used was the measures of central tendency (mean, median and fashion) and percentages that supported the analysis of the results, all with the support of Excel. Results tables were used for the presentation of results. In this chapter the results obtained through the questionnaires that were made to the main governing body of the base consortium of this study in a given time, surveys applied to the president and future substitute, as well as their interpretation and observation of those involved are shown during various moments during the development of the Group's management, when a generational change is being implemented in senior management.

\section{Population and sample}

Sources of consultation both documentary and field

1) Places: Internet portals, libraries and archives of companies.

(C) 2019, IJSMS

Page 32 
2) Types of sources: Books, research articles and thesis

3) Quality of the sources: Primary and secondary

Delimitation of the universe

1) Indication of inclusion characteristics: Family business in process of succession in the top management

2) Geographical or spatial delimitation: The city of Veracruz

3) Temporal delimitation: 2016, which is the year in which the succession process took place.

4) Exact number of members of the universe: 9

Selection of the sample.

As it is a study of a particular case, the determination of a sample does not apply.

Documentary techniques

In the present investigation, bibliographic records and electronic worksheets will be used as documentary techniques.

Selection of field collection techniques

1) Techniques used: Surveys, interviews and observation.

2) Justification of the selection: For the type of descriptive research, surveys are required to be carried out with the personnel directly involved in the research and to use as support the bibliographic and work sheets of books, research articles and theses with related subjects.

Table 2. Categories and operationalization of variables

\begin{tabular}{|c|c|c|c|}
\hline Category & Dimension & Indicator & $\begin{array}{l}\text { Specific objective with } \\
\text { which it relates }\end{array}$ \\
\hline \multirow{3}{*}{ Senior Management } & President of the Group & $\begin{array}{l}\text { Highest position / majority } \\
\text { shareholder }\end{array}$ & 1,2 and 3 \\
\hline & Successor of the President & $\begin{array}{l}\text { Successor of the highest position / } \\
\text { majority shareholder }\end{array}$ & 1,2 and 3 \\
\hline & $\begin{array}{l}\text { Managing Director already } \\
\text { in office }\end{array}$ & $\begin{array}{l}\text { Management of the Group of } \\
\text { companies supervising the } 5 \text { main } \\
\text { areas. }\end{array}$ & 1,2 and 3 \\
\hline \multirow{3}{*}{ Shareholders } & $\begin{array}{l}\text { Family Stockholderand } \\
\text { Customs Broker } 1\end{array}$ & $\begin{array}{l}\text { Operating Advisor and part of the } \\
\text { Board of Directors }\end{array}$ & 1 \\
\hline & $\begin{array}{l}\text { Family Stockholder and } \\
\text { Customs Agent } 2\end{array}$ & $\begin{array}{l}\text { Financial Advisor and part of the } \\
\text { Board of Directors }\end{array}$ & 1 \\
\hline & $\begin{array}{l}\text { Non-family shareholder and } \\
\text { Customs Advisor }\end{array}$ & $\begin{array}{l}\text { Administrative and Internal } \\
\text { Control Advisor and part of the } \\
\text { Board of Directors }\end{array}$ & 1 \\
\hline \multirow[b]{2}{*}{ Senior Executives } & Director of Operations & $\begin{array}{l}\text { Supervisor of local operating } \\
\text { managers and therefore of } \\
\text { Foreign Trade operations of all } \\
\text { offices. }\end{array}$ & 1,2 y 3 \\
\hline & Legal Director & $\begin{array}{l}\text { Supervision of the legal area that } \\
\text { includes review of contracts, } \\
\text { review of foreign trade } \\
\text { documents that involve risk to the } \\
\text { patent, advice and training to } \\
\text { internal and external clients. }\end{array}$ & 1,2 and 3 \\
\hline
\end{tabular}




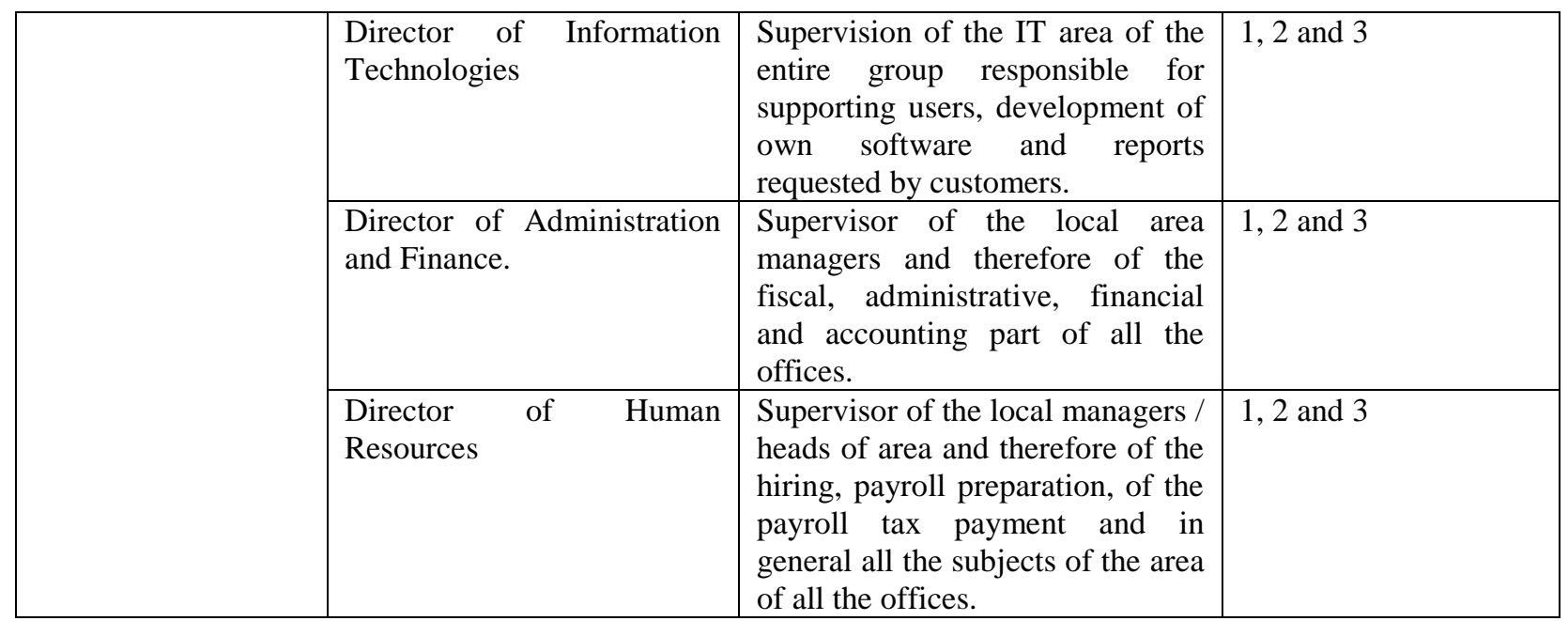

Source: Own elaboration.

Table 3. Technical sheet of the instrument

\begin{tabular}{|c|c|}
\hline First name & Measurement of perception Sense of Belonging and Commitment. \\
\hline Objective & $\begin{array}{l}\text { To measure in the personnel the level of sense of belonging and commitment } \\
\text { towards the company for which they work in a moment of generational } \\
\text { change in the Top Management }\end{array}$ \\
\hline Application form & Self-directed survey \\
\hline Resolution time & Approximately 15 minutes \\
\hline Number of items & 25 items, 3 reagents \\
\hline What measures (indicators) & $\begin{array}{l}\text { - Commitment: obligation that has been contracted or a word already given. } \\
\text { - Identification: refers to the pride, leadership, dedication, recognition, } \\
\text { courage and perseverance that the worker feels for his company. } \\
\text { - Motivation: it is the effort, satisfaction and impulse with which the } \\
\text { collaborator carries out his activities. }\end{array}$ \\
\hline Reagents & $\begin{array}{l}\text { Commitment: } 1,4,6,7,12,14,15,20,22 \text { and } 23 . \\
\text { Identification: } 2,5,8,9,13,17,18,21 \text { and } 25 . \\
\text { Motivation: } 3,10,11,16,19 \text { and } 24 .\end{array}$ \\
\hline Assessment scale & $\begin{array}{l}\text { Each reagent consists of four response options, with the following } \\
\text { assessment and symbology for interpretation, using a Likert scale: } \\
\text { - Totally agree, } 4 \text { points; } \\
\text { - All right, } 3 \text { points; } \\
\text { - Disagree, } 2 \text { points; } \\
\text { - Totally disagree, } 1 \text { point. }\end{array}$ \\
\hline
\end{tabular}

Source: Own elaboration

According to the interpretation obtained in the applied frequency scale, it was classified in the following levels: 
Table 4. Perception criteria

\begin{tabular}{|l|l|}
\hline 1-Fully Agree & 4 \\
\hline 2- Agree & 3 \\
\hline 3- Disagree & 2 \\
\hline 4- Strongly disagree & 1 \\
\hline
\end{tabular}

Source: Own elaboration

Table 5: Score levels

\begin{tabular}{|l|l|l|}
\hline Level & Tap & Description \\
\hline 1 & $25-50$ & Sense of Belonging LOW \\
2 & $51-75$ & Sense of Belonging MEDIUM \\
3 & $76-90$ & Sense of Belonging HIGH \\
4 & $91-100$ & Sense of Belonging VERY HIGH \\
\hline
\end{tabular}

Source: Own elaboration

Table 6: Deployment of the research model

\begin{tabular}{|c|c|c|c|}
\hline Category & Dimension & Indicator & Items \\
\hline \multirow{3}{*}{$\begin{array}{l}\text { Senior } \\
\text { Management }\end{array}$} & Group President & $\begin{array}{l}\text { Higher position / majority } \\
\text { shareholder }\end{array}$ & $\begin{array}{l}\text { What is the perception of sense of } \\
\text { belonging and commitment in a } \\
\text { generational change in senior } \\
\text { management? }\end{array}$ \\
\hline & $\begin{array}{l}\text { Successor of the } \\
\text { president }\end{array}$ & $\begin{array}{l}\text { Successor of the highest position / } \\
\text { majority shareholder }\end{array}$ & $\begin{array}{l}\text { What is the perception of sense of } \\
\text { belonging and commitment in a } \\
\text { generational change in senior } \\
\text { management? }\end{array}$ \\
\hline & $\begin{array}{l}\text { Managing Director } \\
\begin{array}{l}\text { already in office } \\
\text { (replacing the } \\
\text { previous retiree) }\end{array} \\
\end{array}$ & $\begin{array}{l}\text { Management of the Group of } \\
\text { companies supervising the } 5 \text { main } \\
\text { areas. }\end{array}$ & $\begin{array}{l}\text { What is the perception of sense of } \\
\text { belonging and commitment in a } \\
\text { generational change in senior } \\
\text { management? }\end{array}$ \\
\hline \multirow{3}{*}{ Shareholders } & $\begin{array}{l}\text { Family shareholder } 1 \\
\text { and Customs Agent }\end{array}$ & $\begin{array}{l}\text { Operative Advisor and part of the } \\
\text { Board of Directors }\end{array}$ & $\begin{array}{l}\text { What is the perception of sense of } \\
\text { belonging and commitment in a } \\
\text { generational change in Senior } \\
\text { Management? }\end{array}$ \\
\hline & $\begin{array}{l}\text { Family Shareholder } \\
2 \text { and Customs } \\
\text { Agent }\end{array}$ & $\begin{array}{l}\text { Financial Advisor and part of the } \\
\text { Board of Directors }\end{array}$ & $\begin{array}{l}\text { What is the perception of sense of } \\
\text { belonging and commitment in a } \\
\text { generational change in senior } \\
\text { management? }\end{array}$ \\
\hline & $\begin{array}{l}\text { Non-family } \\
\text { shareholder and } \\
\text { Customs Agent }\end{array}$ & $\begin{array}{l}\text { Administrative and Internal } \\
\text { Control Advisor and part of the } \\
\text { Board of Directors }\end{array}$ & $\begin{array}{l}\text { What is the perception of sense of } \\
\text { belonging and commitment in a } \\
\text { generational change in Senior } \\
\text { Management? }\end{array}$ \\
\hline \multirow[t]{2}{*}{$\begin{array}{l}\text { Senior } \\
\text { Executives }\end{array}$} & $\begin{array}{l}\text { Director } \\
\text { Operations }\end{array}$ & $\begin{array}{l}\text { Supervisor of local operating } \\
\text { managers and therefore of Foreign } \\
\text { Trade operations of all offices. }\end{array}$ & $\begin{array}{l}\text { What is the Perception of the sense of } \\
\text { belonging and commitment, of the } \\
\text { lack of confidence when leaving the } \\
\text { leadership in young hands and / or of } \\
\text { an improvement in the mentioned } \\
\text { moment of generational change? }\end{array}$ \\
\hline & Legal Director & Supervision of the legal area that & What is the perception of the sense of \\
\hline
\end{tabular}




\begin{tabular}{|c|c|c|}
\hline & $\begin{array}{l}\text { includes review of contracts, } \\
\text { review of foreign trade documents } \\
\text { that involve risk to the patent, } \\
\text { advice and training to internal and } \\
\text { external clients. }\end{array}$ & $\begin{array}{l}\text { belonging and commitment, of the } \\
\text { lack of confidence when leaving the } \\
\text { leadership in young hands and / or of } \\
\text { an improvement in the moment of } \\
\text { generational change? }\end{array}$ \\
\hline $\begin{array}{l}\text { Director } \\
\text { Information } \\
\text { Technologies }\end{array}$ & $\begin{array}{l}\text { Supervision of the IT area of the } \\
\text { entire group responsible for } \\
\text { supporting users, development of } \\
\text { own software and reports } \\
\text { requested by customers. }\end{array}$ & $\begin{array}{l}\text { What is the perception of the sense of } \\
\text { belonging and commitment, of the } \\
\text { lack of confidence when leaving the } \\
\text { leadership in young hands and / or of } \\
\text { an improvement in the moment of } \\
\text { generational change? }\end{array}$ \\
\hline $\begin{array}{lr}\text { Director } & \text { of } \\
\text { Administration } & \text { and } \\
\text { Finance. }\end{array}$ & $\begin{array}{l}\text { Supervisor of the local area } \\
\text { managers and therefore of the } \\
\text { fiscal, administrative, financial } \\
\text { and accounting part of all the } \\
\text { offices. }\end{array}$ & $\begin{array}{l}\text { What is the perception of the sense of } \\
\text { belonging and commitment, of the } \\
\text { lack of confidence when leaving the } \\
\text { leadership in young hands and / or of } \\
\text { an improvement in the moment of } \\
\text { generational change? }\end{array}$ \\
\hline $\begin{array}{l}\text { Director of Human } \\
\text { Resources }\end{array}$ & $\begin{array}{l}\text { Supervisor of the local managers / } \\
\text { heads of area and therefore of the } \\
\text { hiring, payroll preparation, of the } \\
\text { payroll tax payment and in general } \\
\text { all the subjects of the area of all } \\
\text { the offices. }\end{array}$ & $\begin{array}{l}\text { What is the perception of the sense of } \\
\text { belonging and commitment, of the } \\
\text { lack of confidence when leaving the } \\
\text { leadership in young hands and / or of } \\
\text { an improvement in the moment of } \\
\text { generational change? }\end{array}$ \\
\hline
\end{tabular}

Source: Own elaboration

\section{Analysis of Results}

\section{A. Results of the Survey}

Department in which the respondents work (including minority partners who perform managerial functions in some area of the Group).

Table 7: Respondents

\begin{tabular}{|l|l|}
\hline Management & 2 \\
\hline Information technologies & 1 \\
\hline Legal & 1 \\
\hline Operation & 1 \\
\hline General direction & 1 \\
\hline Presidency & 2 \\
\hline Total & 8 \\
\hline
\end{tabular}

Source: Own elaboration

Gender: Man 7 Woman 1

Table 8: Time to work in the company.

\begin{tabular}{|l|l|}
\hline From 1 to 5 years & 0 \\
\hline From 5 to10 years & 0 \\
\hline from 10 years and up & 8 \\
\hline
\end{tabular}

Source: Own elaboration 
Table 9: Schooling (mark the last completed cycle)

\begin{tabular}{|l|l|}
\hline Primary education & \\
\hline Secondary education & \\
\hline High school education & 1 \\
\hline University studies & 2 \\
\hline Master's or Postgraduate 5 & 5 \\
\hline
\end{tabular}

Source: Own elaboration

Table 10: Age fulfilled.

\begin{tabular}{|l|l|}
\hline Years & No of persons \\
\hline Under 30 & 2 \\
$31-36$ & 1 \\
$37-42$ & 1 \\
43 onwards & 4 \\
\hline
\end{tabular}

Source: Own elaboration

Table 11: Summary of results of the reagents

\begin{tabular}{|c|c|c|c|c|c|c|c|c|c|c|c|c|c|c|c|c|c|c|c|c|c|c|c|c|c|c|}
\hline & \multicolumn{25}{|c|}{ REACTIVOS } & \multirow[b]{2}{*}{ TOTAL } \\
\hline Encuestado & 1 & 2 & 3 & 4 & 5 & 6 & 7 & 8 & 9 & 10 & 11 & 12 & 13 & 14 & 15 & 16 & 17 & 18 & 19 & 20 & 21 & 22 & 23 & 24 & 25 & \\
\hline 1 & 1 & 1 & 1 & 1 & 1 & 1 & 1 & 1 & 2 & 1 & 3 & 1 & 1 & 1 & 1 & 1 & 1 & 1 & 2 & 1 & 1 & 1 & 1 & 1 & 1 & 96 \\
\hline 2 & 1 & 1 & 1 & 1 & 1 & 1 & 1 & 1 & 3 & 1 & 3 & 1 & 1 & 1 & 1 & 1 & 1 & 1 & 1 & 1 & 1 & 1 & 1 & 1 & 1 & 96 \\
\hline 3 -Direct Área & 1 & 1 & 1 & 1 & 1 & 1 & 1 & 1 & 1 & 1 & 1 & 1 & 1 & 1 & 1 & 1 & 1 & 1 & 1 & 1 & 1 & 1 & 1 & 1 & 1 & 100 \\
\hline 4 - Socio & 1 & 1 & 2 & 1 & 1 & 1 & 1 & 1 & 1 & 1 & 3 & 1 & 1 & 2 & 1 & 1 & 1 & 1 & 1 & 1 & 1 & 1 & 1 & 1 & 1 & 100 \\
\hline $5-A D$ & 1 & 1 & 1 & 1 & 1 & 1 & 1 & 1 & 1 & 1 & 1 & 1 & 1 & 1 & 1 & 1 & 1 & 1 & 1 & 1 & 1 & 1 & 1 & 1 & 1 & 100 \\
\hline 8 -Socio & 1 & 1 & 1 & 1 & 2 & 1 & 1 & 2 & 1 & 2 & 1 & 1 & 1 & 1 & 1 & 1 & 1 & 1 & 1 & 1 & 1 & 1 & 1 & 1 & 1 & 97 \\
\hline romedio & 4 & 4 & 3.8 & 4 & 3.8 & 4 & 4 & 3.9 & 3.6 & 3.8 & 3.3 & 4 & 4 & 3.9 & 4 & 4 & 4 & 4 & 3.9 & 4 & & & 4 & & & \\
\hline
\end{tabular}

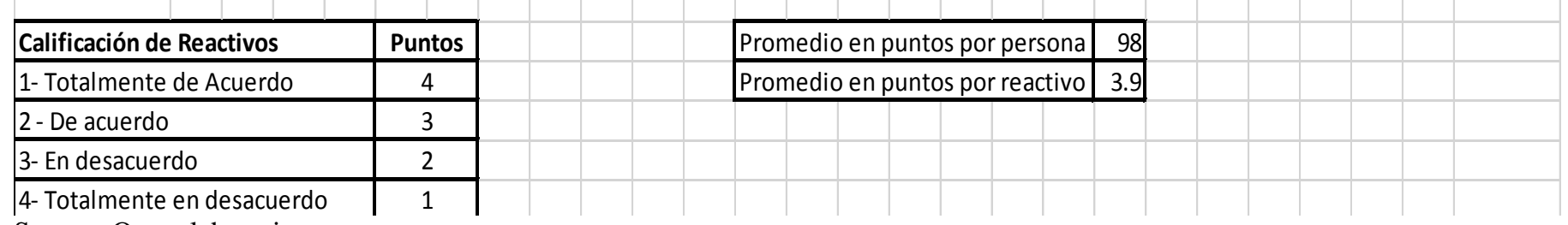

Source: Own elaboration

\section{B. Interviews with the current president and the substitute}

In order to identify the perception of the sense of belonging, the success of the succession process and the support received from the main managers and employees during the same, a separate survey was conducted to the current president and the person who is in training for replace it, who is your son. The surveys were conducted in the transition period of the succession of the position of Presidency of the Consortium of companies dedicated to foreign trade, the basis of this study, separately and in a neutral environment.

\section{Descriptive analysis}

It was divided the reagents of the survey applied to the main Managers and directors of the Group in three levels, commitment, identification and motivation in the following way: 
a) Commitment: 1, 4, 6, 7, 12, 14, 15, 20, 22 and 23 .

b) Identification: 2, 5, 8, 9, 13, 17, 18, 21 and 25 .

c) Motivation: 3, 10, 11, 16, 19 and 24 .

Based on the results obtained from the surveys, we can identify the following:

a) Commitment - The people surveyed as part of the sample, are highly committed to the company and the executives of the same and that has not changed during the generational process, achieving the highest score of the three levels with an average value of 3.99 , being the highest 4.00

b) Identification. - People identify with the company inside and outside of it and feel proud to belong to the Group and consider the succession of the Group Presidency as their own change, achieving an average of 3.93 points, the highest value being 4.

c) Motivation. - Employees are motivated to do their work day by day, since the Group offers a good working environment, excellent facilities and benefits above what is offered in the market, a situation that has even improved in the succession process of the Presidency. Although the average was lower than the other two levels, it is still a high value, obtaining an average of 3.80 points out of a total of 4 .

Comparing the results of the questionnaires with those of other studies, it was perceived a high sense of commitment and belonging to the company. Staff turnover is low and that has improved during the process of succession of the Group Presidency, as working conditions improved.

From a different survey applied to the president and the future successor, it is shown that although they have different ways of thinking, both are focused on the same succession plan, highlighting the following points:

a) They are $100 \%$ committed to the succession plan.

b) The succession project has been planned for many years and had external advice.

c) The Group's main directors have been working for it for many years, so they were informed at all times and have been part of this process.

d) The differences of opinion derived from the generation gap have achieved an important synergy by combining the best of the experience of the generation that is leaving the leadership, with the innovation of the "Y" generation, achieving better results in the Group.

e) It is estimated that the succession process will end in three years, time in which the internal and external successor training will end, considering as internal, the experience that should continue to obtain to be the president of such a large and important Group in Foreign Trade Nationally.

f) f) As a result of the surveys applied both to the President of the Group and to the successor, it is evident that both are fully committed to the process, have the support of the principal directors of the group, and although there are some differences of opinion due to the generation gap, they have known how to merge both experience and innovation, resulting in growth in the Group, at the time of the study.

g) The success of the succession process that takes so far, is because it has been planned for years, as the president's son was the only viable candidate to succeed him, so many projects were carried out thinking about this succession. They were advised by an external office, which included the main directors to feel part of the changes.

\section{General data of the respondents}

1) The current president is over 60 years old and the substitute is less than 30 years old. Both are male.

2) Only $10 \%$ of the respondents are female.

3) $100 \%$ of the respondents have more than 10 years of working in the companies of the group, so they feel part of it.

4) $25 \%$ is under 30 years old, considered "Y" generation, including the substitute. 
5) 3 of the 8 managers or those in charge of the main areas are minority partners and are relatives of the president and his substitute and there are no more relatives working in the companies.

\section{E. Results of observation}

Although this research was recently started, working within the Consortium base of this study has allowed me to observe the changes that are taking place as the substitute has become involved in the group's questions.

During the boards of directors where all those involved in the current investigation are present, it has been observed that the substitute is having more and more participation and his ideas have been taken into account. These ideas have been accepted by the current president, although they are considered avant-garde (and at other times he had not accepted them). For example, an improvement in the schedule, grant English classes to staff, flexibility in dressing on Fridays, modifications that have generated a decrease in staff turnover and have been very well accepted. The nonverbal language in managerial meetings where everyone agrees, is acceptable and pleasing to show support in most of the proposals and decisions of the substitute.

The increasing incorporation of the substitute throughout the last months, the acceptance of his proposals and the nonverbal language observed in the meetings of the Council and others in which both the substitute and the other directors are present show that the latter, as well as the leader of the consortium, they have a favorable disposition to accept the substitute. This impression derived from the observation was reinforced with the information obtained in the applied surveys.

\section{Conclusions}

The success of the succession process depends on a series of circumstances that must exist and above all prepare with due time. In the case studied, a preparation was carried out that lasted several years, including establishing the requirements of the successor, the previous preparation of the same and the inclusion in the process of the main leaders of the Group, so that point, unlike other investigations where the response was not favorable, it was considered made the difference for the success of the development of the succession.

When studying the dimensions of the sense of belonging and commitment that shareholders and senior managers have in a moment of succession of the presidency of the base consortium of this study, it was found that everyone is really committed and part of the company, and that feeling is not changes, although a succession is taking place in the highest position of the company, which is occupied by the majority shareholder. All are focused on the proper functioning of the companies that are part of the Consortium and are part of the successful succession process at the time of the investigation.

According to the results of the empirical observation of the Consortium, the same level of ownership and commitment can be seen in both senior executives and shareholders who feel part of the company and therefore are interested in the succession process being successful.

The three indicators used in the present investigation came out at an above-average level. These high levels of organizational commitment that commonly originate in the successful family business tradition, are related to the preservation of the surname, which is synonymous with pride for family shareholders, and in this case also for nonfamily managers, as they feel part of the company and therefore it is also pride that the family name, usually included in the name of companies, is preserved through the years.

This sense of pride and belonging can be the trigger for greater dedication and commitment in the company, extended to Altos direct with more than 10 years in the company (Vallejo, 2007). Unlike the results of other research, where the high sense of commitment and dedication in the company, depends only on the share percentage, in the Consortium that is studied in this document, the level of commitment is high when they have already a considerable antiquity in companies, in this example, more than 10 years, already feeling part of the company, even if they are not partners.

(C) 2019, IJSMS

Page 39 
Succession is easier if the leader is predisposed to delegate, disengage, be generous, grant autonomy and not interfere, establish trusting relationships with his family and collaborators (Araya 2011). In the study carried out, it is noted that in the part of the process where he is, the leader has met these requirements, preparing for this moment for several years and with the advice of an office dedicated to these issues, which increases the success rate in this process.

Because of the importance of the topic, it is recommended to involve all the staff in the expected change, explaining with clear goals and objectives what is expected of them and what can happen if the succession of the group of companies is not successful. In addition to the above and as a last point, an agent of change will achieve better results by being out of the company and not involved in any process. It will give the necessary courses to reinforce the sense of belonging of the employees and therefore the motivation through incentives, "T" workshops, etc.

For all the aforementioned, and carrying out the recommended reinforcement, it is expected that the process of generational succession in the group leader will be carried out successfully.

\section{References}

[1] Araya, A. (2011). La sucesión de empresasfamiliarescostarricenses: factores de éxito y fracaso. Tesis Doctoral, Universidad de Valencia, España.

[2] Aronoff, C.E. y Ward, J.L. (1995). Family-owned businesses: A thing of the past or Review, 8: 121- 130.

[3] Belausteguigoitia, I. (2010). Empresasfamiliares, sudinámica, equilibrio yconsolidación. México, D.F.: Mc Graw-Hill.

[4] Cabrera, K. (1998). Factoresdeterminantes del éxito y fracaso del procesode sucesiónen la empresa familiar(Tesis Doctoral). Recuperado de la base de datos de la Universidad de las Palmas de Gran Canaria. España 1998.

[5] Chittoor, R. y Das, R. (2007). Professionalization of management and successionperformance - a vital linkage. Family Business Review, 20(1), 65-79.

[6] Chrisman, J., Chua, J. y Sharma, P. (1998). Important attributes of successors infamily businesses: an exploratory study. Family Business Review, 11(1), 19-34.

[7] Friedman, M. y Friedman, S. (1994). How to Run a Family Business. Cincinnati,Ohio: Beterway Books.

[8] Gallo, M. (1995). Empresa familiar: Textos y casos. Barcelona: Editorial Praxis.

[9] García-Tenorio, J. y Pérez, M. (2009). El relevogeneracional y la estrategia derecursoshumanosen la empresa familiar. Recuperado de la base de datos de la Universidad Complutense de Madrid. España 2009.

[10] Handler, W. (1989). Managing the family firm succession process: The next- generation family member's experience. UMI Dissertation Services.

[11] Handler, W.(1994). Succession in family business: A review of the research. FamilyBusiness Review, 7:133-157.

[12] Herrera, G. (2012). Relación entre sentido de pertenencia y estabilidadlaboral. Tesisinédita. Universidad Rafael Landivar. Guatemala

[13] Jurado, A (2014). Los niveles de sentido de pertenenciaen un grupo de profesionalesbajocontrataciónlaboralsimuladaendistintasorganizacionesguatemaltecas. Universidad Rafael Landivar. Guatemala. Leach, P. (1993). La empresa familiar. Barcelona: EdicionesGranica.

[14] Lewin, K. (1947). Frontiers in Group Dynamics: Concept, method, and reality in social science; social equilibria and social change. Retrieved from Sage Journals: http://journals.sagepub.com/doi/abs/10.1177/001872674700100103

[15] Longenecker, J., Moore, C. y Petty, W. (2001). Administración de pequeñasempresas. México: Thomson Learning.

[16] Nelton, S. (1993). Why don’t we dish the dirt.Family businessReview.. E.U.A.: pp.81, 61.

[17] Oviedo, G. (2004). La definición del concepto de percepciónenpsicología con baseen la Teoría Gestalt. Revista de EstudiosSociales. No 18. Bogotá, Colombia. Mayo/Agosto 2004.

[18] PricewaterhouseCoopers, Instituto de la Empresa Familiar y Red de Cátedras delIEF (2007): "Políticas de Capital humanoen la Empresa Familiar",Documento 142 del IEF.

[19] Quijano, R., Magaña, D., Perez, C. (2011).Pertenencia y compromiso: factoresrelevantesen la transicióngeneracional de empresasfamiliares. $\begin{array}{llllll}\text { Casoconstructoras } \quad \text { Campeche, México. EstudiosGerenciales, } 27 & \text { (121), 99-114. Recuperado }\end{array}$ dehttps://www.icesi.edu.co/revistas/index.php/estudios_gerenciales/article/view/1119.
(C) 2019, IJSMS
Page 40 
[20] Sharma, P. e Irving, G. (2005). Four bases of family business successor commitment: antecedents and consequences. Entrepreneurship Theory and Practice.Documento29(1), 2005, 13-33.

[21] Ussman, A. (2004). EmpresasFamiliares. Lisboa: Editorial Silabo.

[22] Vallejo, M. (2007). El compromiso de la empresa familiar bajounaóptica de liderazgotransformacional y aprendizajeorganizacional. InvestigacionesEuropeas de Dirección y Economía de la Empresa, 13 (3), 217-234.

[23] Vancil, R. (1987). Passing the batan: Managing the process of CEO succession. MA, EstadosUnidos. Harvard Business School Press.

[24] Vilaseca, A. (2002). The shareholder role in the family business: conflict of interests and objectives between nonemployed shareholders and top management team. Family Business Review, 15(4), 299-320.

\begin{tabular}{|c|c|c|c|c|c|}
\hline \multicolumn{6}{|c|}{ Instrument } \\
\hline & & 4 points & 3 points & 2 points & 1 point \\
\hline No. & Statement & $\begin{array}{l}\text { Strongly } \\
\text { Agree }\end{array}$ & Agree & Disagree & $\begin{array}{l}\text { Strongly } \\
\text { disagree }\end{array}$ \\
\hline 1 & I like to dedicate myself to the work I do in this company & 8 & & & \\
\hline 2 & When I hear strangers speak well about the company I feel proud & 8 & & & \\
\hline 3 & I rarely consider my work monotonous or boring & 6 & 2 & & \\
\hline 4 & Even if my superior does not ask me, I like to do my job well & 8 & & & \\
\hline 5 & $\begin{array}{l}\text { I feel a greater commitment to the generational change that is taking place in } \\
\text { the Presidency }\end{array}$ & 6 & 2 & & \\
\hline 6 & I dedicate more time to my work than corresponds to me & 8 & & & \\
\hline 7 & $\begin{array}{l}\text { I have a commitment to the company for all that I have received from it, } \\
\text { regardless of whether there is a change in senior management with a new } \\
\text { generation in charge }\end{array}$ & 8 & & & \\
\hline 8 & If possible I would like to work in this company for a long time & 7 & 1 & & \\
\hline 9 & If I could I would bring my family or friends to work for this company & 6 & 1 & 1 & \\
\hline 10 & $\begin{array}{l}\text { Belonging to this company living a successful generational change in top } \\
\text { management motivates me to do my best }\end{array}$ & 6 & 2 & & \\
\hline 11 & My colleagues realize my encouragement and motivation to do the job & 5 & & 3 & \\
\hline 12 & $\begin{array}{l}\text { I show loyalty to the company in the activities I did before, during and after } \\
\text { the generational change }\end{array}$ & 8 & & & \\
\hline
\end{tabular}




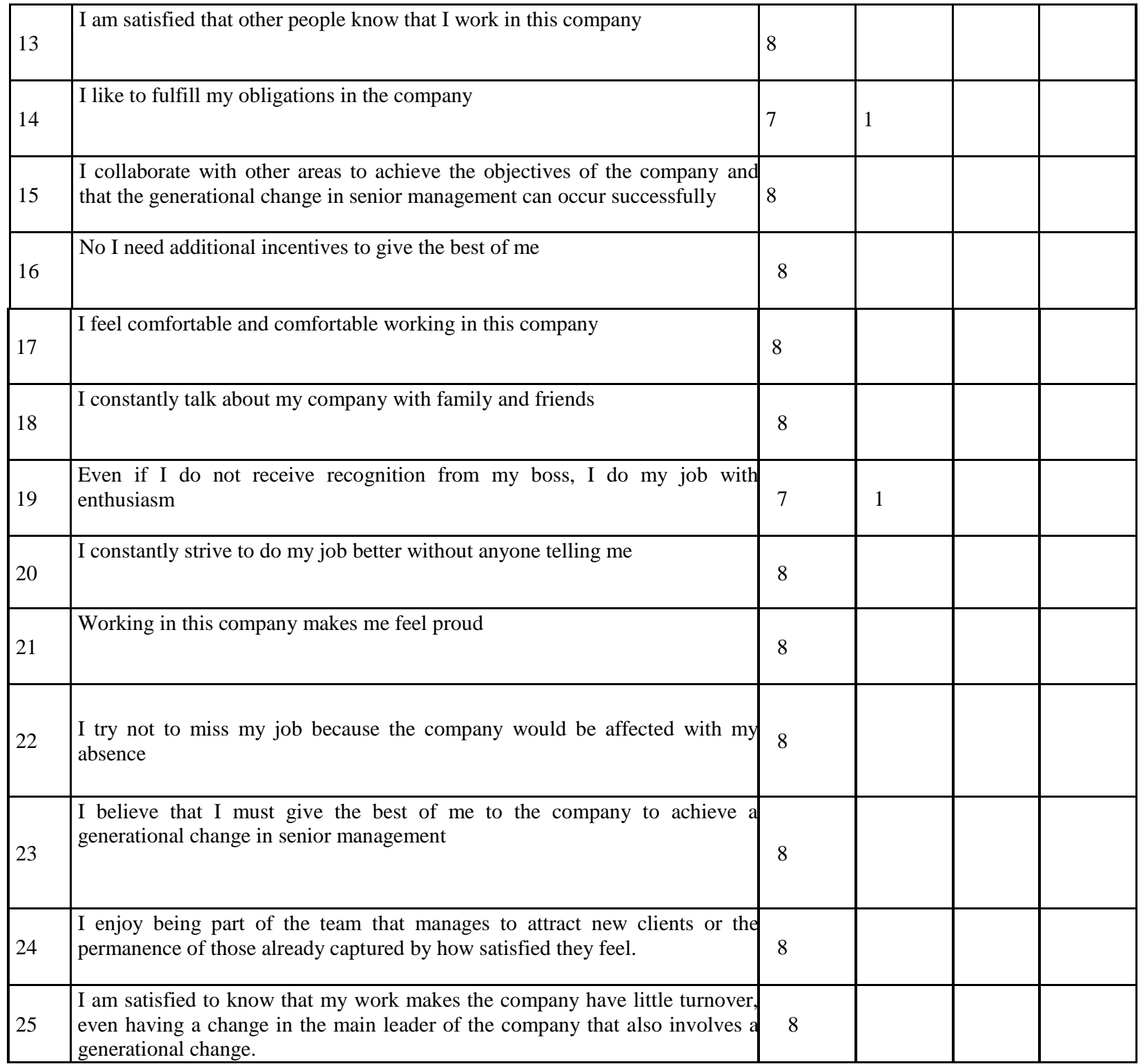

\section{ANNEX B}

\section{Interview with the current President}

\section{1.- Do you consider that the change of leader in the Group of companies is taking place at the opportune moment?}

Time is the perfect one. In addition to analyzing it, we have external consultants who are helping us during this process. My son has been in the company for some time now, which has allowed him to see how the companies he will have under his charge work, how to control, supervise and make them grow, together with the diversity they have in an area as complex as it is foreign trade. In addition to the above, is finishing training both within the company and outside of it through a postgraduate abroad, which will bring new ways of seeing things, work and be able to merge with what has so far been success in the company. This merger will allow a modernization and constant improvement of our processes, which will result in a better result in both profits and living conditions for employees and partners.

\section{2.- Have you felt that the main executives of the company have doubts about the change of the leader of the Group?}

No. The main executives of the company have been working with the Group for more than 10 years and everyone knew that this 
change would take place, since we are a family business with only one possible successor. Therefore, all have supported the process of succession from the beginning.

3.- The main leaders of the group, do they have confidence in the future leader of the Group and its preparation?

Yes. They trust both my son and my criteria and have seen the work that has been done, as well as the maturation process that led to the current president of this Group at the present time.

\section{4.- Do you consider that the future leader is ready to take responsibility?}

Within the process that is planned, it goes on time. The project is estimated so that in 3 more years, I will retire completely and my son will be in charge of the Group that we have formed, as president.

5.- Did you speak before doing the projects to replace the presidency with the main executives of your companies?

As I mentioned earlier, for the years that everyone has been working within the Group, everyone was always aware. Having trained personnel in the main areas has allowed to grow and have the place it has in the country today, as well as being freer from foreign trade companies and dedicating myself to other things.

\section{6.- Have you found important differences in the way you manage the company between you and your successor?}

Of course. First of all, we are two generations and two completely different ideologies. But the fusion between experience and youth that we are achieving has merged perfectly. We have modernized the processes, making them more efficient, making sure that employees are convinced that we are the best option to work and that is why they understand the needs of the company and of the clients, who in the end, are the ones we sell our service to.

\section{7.- How long do you think it is still necessary for the process of replacing the Chair of the Group to be completed?}

Three years according to our project.

8.- How did the main executives and the Group's workforce react when they learned that a change in the presidency was going to take place?

Being a subject they already knew about, when they commented they took it as something natural in the process of a family business.

9.- The generation gap between the current president and the substitute in training, has it meant a bigger problem because of the different ideologies?

No. On the contrary. A very important merger has been made with the main strengths of the two generations.

10.- How have you overcome these differences?

Taking the best of the two generations, making it a fortress.

11.- What expectations do you have regarding employee commitment after the succession of the Group president?

$100 \%$ commitment, as has been the case so far.

12.- What do you expect to happen with the rotation of personnel when the succession of the president of the Group has occurred and during the process?

Let it decrease.

\section{ANNEX C \\ Substitute Interview}

1.- Do you consider that the change of leader in the Group of companies is taking place at the opportune moment?

The moment was excellent. It has allowed me to spend a few years in the company, know how it works, what can continue to work and how to improve it. Many things have been modernized, and although it is not easy to change the way of thinking of those who have done it in a certain way for many years, in the end that vote of confidence has been given to me and the results are palpable. The union of experience of the previous generation with the innovation of the "Y" generation is resulting in a stronger company, with more involved personnel and with the certainty that they work for the best company.

2.- Have you felt that the main executives of the company have doubts about the change of the leader of the Group?

No. Everyone knew them for several years and it was something they already knew was going to happen. All have been
(C) 2019, IJSMS
Page 43 
supporting the process and although there have been differences in the ways of thinking about some issues, in the end they have complemented my ideas with their experience and helped carry out the changes.

3.- The main leaders of the group, do they have confidence in the future leader of the Group and its preparation?

Yes. All have shown confidence and have seen that the changes and ideas that I bring have generated added value to the company.

\section{4.- Do you consider that the future leader is ready to take responsibility?}

We are within the times that we established from the beginning, but I still will not take full responsibility. That is estimated for a maximum of 3 years, during which time I will study a postgraduate abroad with the possibility of opening a branch in the place where I am living and start to provide logistics and marketing services. This will allow us to have a presence abroad and when I return to take the full reins of the Group, leave the office running $100 \%$.

\section{5.- Did you speak before doing the projects to replace the presidency with the main executives of your companies?}

Yes, this topic was always discussed with them as the pillars of the Group.

6.- Have you found important differences in the way you manage the company between you and your future predecessor?

Yes, but the existing processes have been adapted to my proposals, reaching a mid-point. This has allowed us to improve customer service and therefore the recruitment of new customers, without losing sight of the quality of life of employees.

7.- How long do you think it is still necessary for the process of replacing the Chair of the Group to be completed?

Three years.

8.- How did the main executives and the Group's workforce react when they learned that a change in the presidency was going to take place?

They reacted in a positive way. The beginning of the process coincided with the retirement of two of the people who had more years in the company, but that was also something that we already knew was going to happen over the years of the people, so they had the support until their departure, and of the people who continue in the company, 100\% support has been obtained.

9.- The generation gap between the current president and the substitute in training, has it meant a bigger problem because of the different ideologies?

No. Changes have been made to modernize the processes and adapt them to the current world.

\section{0.- How have you overcome these differences?}

The experience of previous generations is taken as a basis, adapting it to the current management situation and forms.

\section{1.- What expectations do you have regarding employee commitment after the succession of the Group president?}

That the degree of commitment not only remains the same, but improves. I have won the trust and will continue to do with my actions.

12.- What do you expect to happen with the rotation of personnel when the succession of the president of the Group has occurred and during the process?

I hope that the rotation of personnel is minimal and only of the personnel that do not agree with the values and policies of the Group. 